\title{
Acceptance of antiviral treatment and enhanced service model for pregnant patients carrying hepatitis B
}

\author{
PW Hui *, Carmen Ng, KW Cheung, CL Lai
}

\begin{abstract}
A B S T R A C T
Introduction: A service model was established for pregnant women with positive screening results for hepatitis B surface antigen (HBsAg) at Queen Mary Hospital in Hong Kong. All women were offered a blood test for hepatitis B virus (HBV) DNA level during the first antenatal visit. Women with $\mathrm{HBV}$ DNA levels of $\geq 200000 \mathrm{IU} / \mathrm{mL}$ received counselling from hepatologists regarding treatment with antenatal tenofovir disoproxil fumarate (TDF) $300 \mathrm{mg}$ daily.
\end{abstract}

Methods: This retrospective review included women attending our antenatal clinic who exhibited positive HBsAg screening results from 15 May 2017 to 31 December 2019. The proportions of women with positive HBsAg, DNA test acceptance, hepatological review, and TDF acceptance during pregnancy were reviewed.

Results: In total, 375 (2.9\%) of 13082 pregnant women had positive HBsAg screening results. Blood tests for HBV DNA and hepatological reviews were offered to 273 women who had not undergone hepatological review prior to pregnancy; the women were hepatitis B carriers with high viral loads of $\geq 200000 \mathrm{IU} / \mathrm{mL}$. Among 58 women with high viral loads, 57 received antenatal counselling regarding TDF and $56(96.6 \%)$ agreed to take the drug; $92.9 \%$ of these 56 women had commenced TDF at or before 32 weeks of gestation.

Conclusions: This study indicated broad acceptance of HBV DNA tests by pregnant women. Triage allowed early review and commencement of antiviral medication. This service model serves as a framework for enhanced antenatal service to prevent mother-to-child-transmission in public maternity units.
Hong Kong Med J 2020;26:318-22
https://doi.org/10.12809/hkmj208451
PW Hui *, MD, FHKAM (Obstetrics and Gynaecology)
${ }^{1} \mathrm{C} \mathrm{Ng}, \mathrm{MB}, \mathrm{BS}$
${ }^{1}$ KW Cheung, MB, BS, FHKAM (Obstetrics and Gynaecology)
${ }^{2}$ CL Lai, MD, FHKAM (Medicine)
${ }^{1}$ Department of Obstetrics and Gynaecology, Queen Mary Hospital, Hong Kong
${ }^{2}$ Department of Medicine, The University of Hong Kong, Hong Kong
* Corresponding author: apwhui@hku.hk

New knowledge added by this study

- More than $70 \%$ of the pregnant women in our cohort did not have hepatitis B virus (HBV) viral load testing or regular hepatological surveillance before pregnancy.

- Antenatal testing of HBV DNA level and treatment with tenofovir disoproxil fumarate was widely accepted by pregnant women.

- More than $90 \%$ of pregnant women accepted tenofovir disoproxil fumarate treatment at or before 32 weeks of gestation.

Implications for clinical practice or policy

- HBV DNA testing should be arranged in all pregnant women carrying hepatitis B; triage allows early review and commencement of antiviral medication.

- An enhanced service model involving multidisciplinary assessment and treatment by obstetricians and hepatologists is achievable in a public hospital in Hong Kong.

\section{Introduction}

The World Health Organization aims to eradicate hepatitis B virus (HBV) by 2030 and prevention of vertical transmission is a key element of its eradication efforts. ${ }^{1}$ The risk of chronic infection depends on the timing of infection acquisition and is highest during the perinatal period, such that chronic infection occurs in approximately 90\% of newborns from HBV-infected mothers. ${ }^{2}$ The risk is dramatically reduced by administration of hepatitis B immunoglobulin to newborns at birth, in combination with a complete course of hepatitis B vaccination. ${ }^{3}$ Despite a $75 \%$ to $90 \%$ reduction in the carrier rate with these measures, they have not resulted in complete eradication of HBV infections. Among the maternal and obstetric factors examined, a high maternal HBV DNA level during pregnancy is the strongest risk factor leading to immunoprophylaxis failure. ${ }^{4-7}$

The immunoprophylaxis failure rate in Hong Kong is reportedly $1.1 \%$, according to the results of 
a local prospective multicentre observational study. ${ }^{5}$ Immunoprophylaxis failure occurs only in those women with high viral load (ie, $\geq 6 \log _{10}$ copies $/ \mathrm{mL}$ [ $\geq 171821 \mathrm{IU} / \mathrm{mL}]$; immunoprophylaxis failure rate $4.2 \%$ ) or hepatitis B e-antigen (HBeAg)-positive status (immunoprophylaxis failure rate $4.5 \%$ ). The use of antiviral treatment during the third trimester in highly viraemic mothers to suppress viral load has been advocated to reduce the risk of chronic HBV infection in newborns. ${ }^{8,9}$ To achieve this, it is essential to establish a management strategy that includes HBV DNA assessment for identification of high-risk patients, as well as initiation of prompt antiviral treatment in the antenatal period.

An enhanced service model for pregnant women who had positive screening results for hepatitis B surface antigen (HBsAg) was established on 15 May 2017 at Queen Mary Hospital in Hong Kong (Fig 1). All women were offered blood tests for HBV DNA, performed by the Department of Medicine, The University of Hong Kong, during their first antenatal visits at Tsan Yuk Hospital or Queen Mary Hospital. The cost of HK\$400 per test was borne by the patients; the laboratory results were reviewed by hepatologists.

Pregnant women with HBV DNA levels of $\geq 200000 \mathrm{IU} / \mathrm{mL}$ were triaged by hepatologists for an early clinic appointment, generally before 33 weeks of gestation, to receive counselling regarding potential antiviral treatment. Tenofovir disoproxil fumarate (TDF) $300 \mathrm{mg}$ daily was chosen for its potent efficacy and risk of pre-existing or emergent resistant mutants from previous lamivudine and telbivudine treatments. ${ }^{10-12}$ Drug compliance and HBV DNA level were monitored regularly. All other pregnant women with viral loads of $<200000 \mathrm{IU} / \mathrm{mL}$ were also scheduled for an elective long-term follow-up appointment. Irrespective of viral load, all neonates born from pregnant women with hepatitis B were administered $\mathrm{HBV}$ vaccine and hepatitis $B$ immunoglobulin within 12 hours of birth. The present study aimed to evaluate the patients' acceptance and outcome of this enhanced service model for management of pregnant women carrying hepatitis $B$.

\section{Methods}

This retrospective review included all women who attended the antenatal clinic from 15 May 2017 to 31 December 2019. Information regarding hepatitis B carrier status, HBV DNA blood test acceptance, viral load, patient triage, and TDF acceptance were retrieved from the antenatal record system and clinical management system under the Hong Kong Hospital Authority. The HBV DNA assays were performed in Department of Medicine, The University of Hong Kong.

Each patient's HBV carrier status was determined by an HBsAg test performed during

\section{為乙型肝炎孕婦而設的抗病毒治療和改善 服務模式 \\ 許佩華、吳樹泯、張嘉宏、黎青龍}

引言：瑪麗醫院針對乙肝病毒表面抗原 ( HBsAg) 篩查結果為陽性 的孕婦建立一個服務模式, 於首次產前檢查期間提供乙型肝炎病毒 ( HBV ) DNA水平的血液檢查。HBV DNA水平達200000 IU/mL或 以上的婦女會轉至肝臟科接受每天 $300 \mathrm{mg}$ 抗 $\mathrm{HBV}$ 藥物富馬酸替諾福韋 酯（TDF）治療。

方法：該回顧研究納入2017年5月15日至2019年12月31日在我們產前 診所就診的HBsAg陽性的婦女，分析HBsAg陽性婦女的比例、DNA測 試接受率、肝病學檢查和妊娠期TDF接受率。

結果：13082名孕婦中，375名（2.9\%）的HBsAg篩查結果為陽性。 醫院為2 73 名懷孕前未有肝檢查的婦女提供HBV DNA血液和肝檢 查, 接受率為 $97.8 \%$ 。60名 $(22.6 \%)$ 孕婦是乙肝帶菌者, 病毒載量 $200000 \mathrm{IU} / \mathrm{mL}$ 或以上。58名病毒載量高的婦女中, 57 名接受有關 TDF治療的產前諮詢, 其中56名 (96.6\%) 同意服用該藥。這56名婦 女中, $92.9 \%$ 在妊娠32週或之前開始TDF治療。

結論：這項研究表明孕婦廣泛接受HBV DNA檢測。分流能及早為婦 女檢查和開始抗病毒藥物治療。這種服務模式作為改善公立醫院產前 服務的框架, 有助防止母嬰傳染。

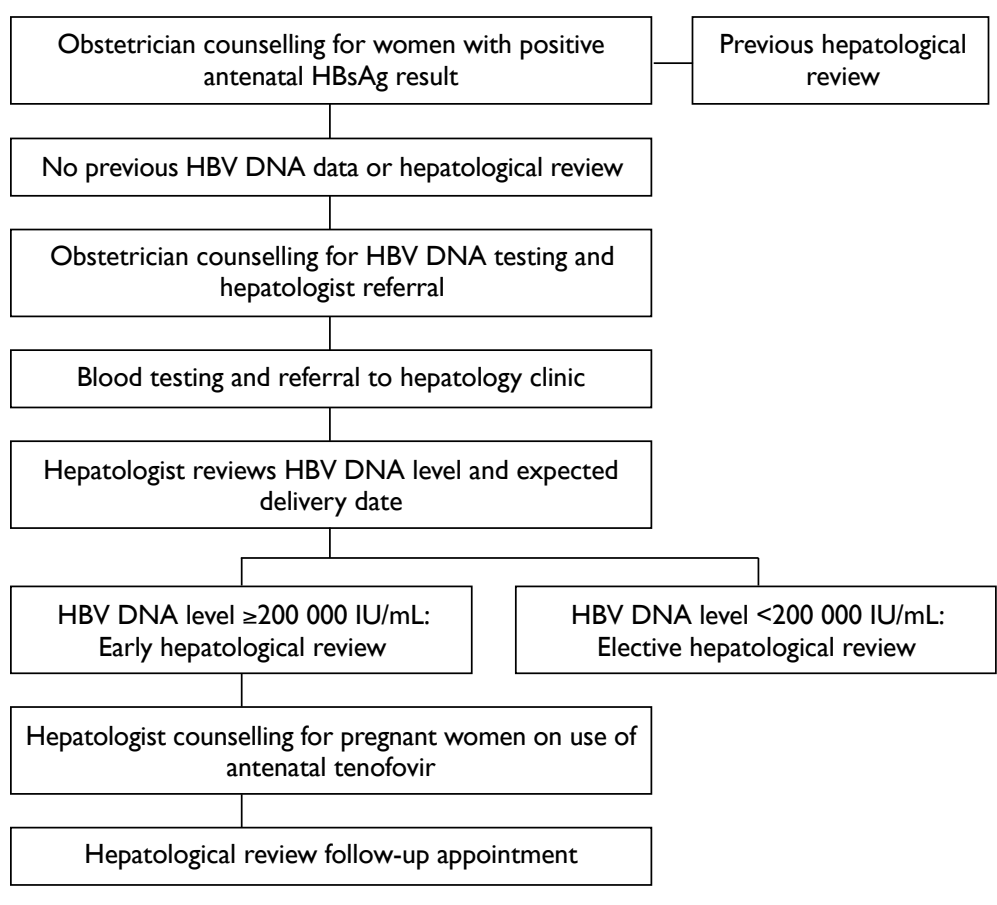

FIG I. Flowchart illustrating enhanced service model for pregnant women carrying hepatitis $B$ virus

Abbreviations: $\mathrm{HBsAg}=$ hepatitis B surface antigen; $\mathrm{HBV}=$ hepatitis B virus

pregnancy. Hepatitis $B$ virus DNA level was considered high for viral loads of $\geq 200000 \mathrm{IU} / \mathrm{mL}$ and low for viral loads of $<200000 \mathrm{IU} / \mathrm{mL}$. The rate of antenatal acceptance of TDF was defined as the proportion of women taking TDF in the group with high viral loads who had been counselled by hepatologists. Descriptive statistics are reported. 


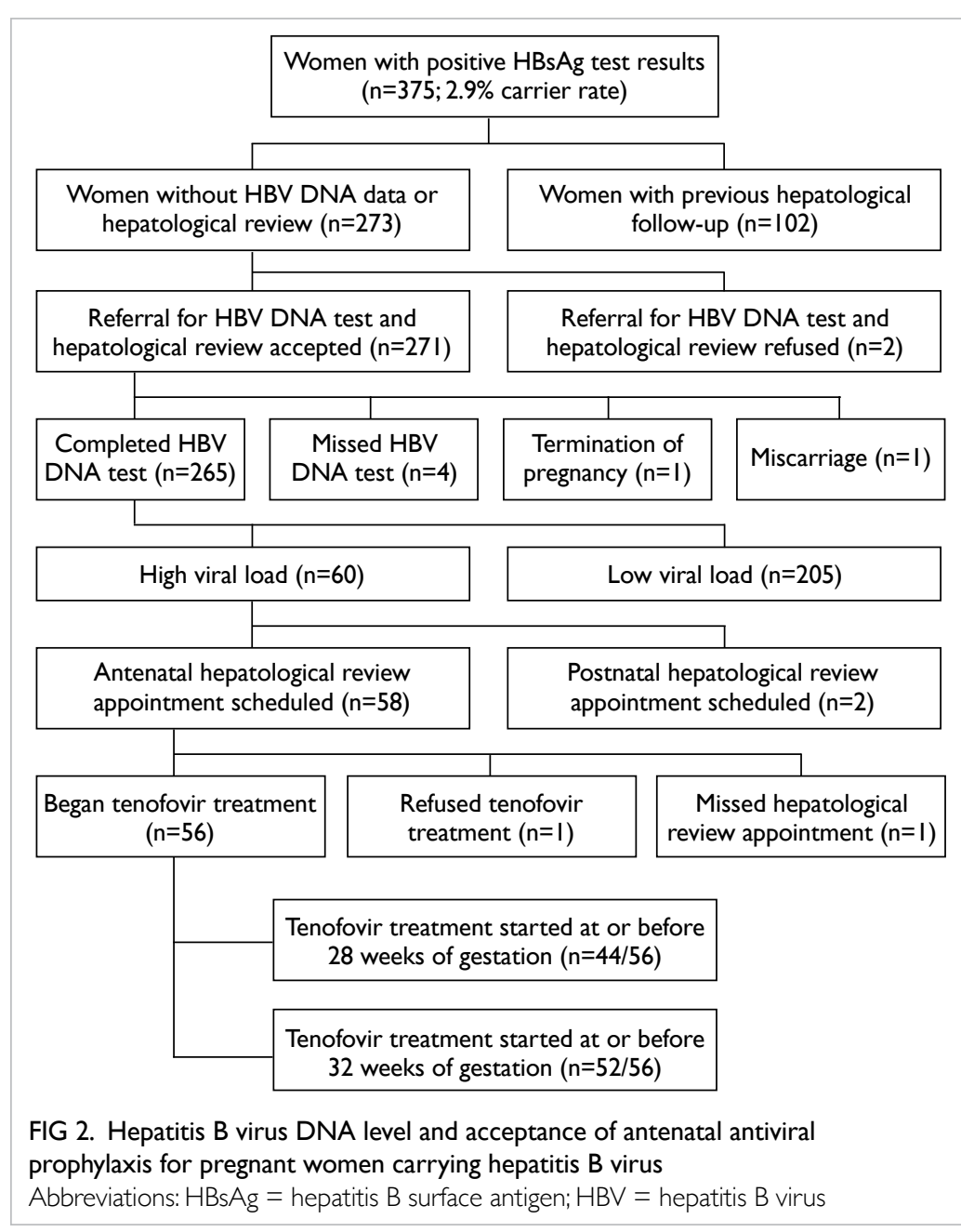

\section{Results}

Of 13082 women who attended the antenatal clinic from 15 May 2017 to 31 December 2019, 375 pregnant women had positive HBsAg screening results; the carrier rate was $2.9 \%$. In total, $102(27.2 \%)$ women had undergone HBV DNA testing or received regular hepatological follow-up before pregnancy. Blood tests for HBV DNA and hepatological reviews were offered to 273 pregnant women. Two women refused further assessment and four women did not attend the blood test visit. Reasons for refusal or non-attendance were not documented. Of the four women who did not attend the blood test visit, two were reminded of the need for a blood test at subsequent antenatal visits, but did not complete the tests. Overall, the acceptance rate for hepatological review was $97.8 \%$ (267/273). Among the 267 women who accepted hepatological reviews, blood tests were not performed because of pregnancy termination due to trisomy $21(\mathrm{n}=1)$ and miscarriage $(\mathrm{n}=1)$. Thus, the final cohort comprised 265 pregnant women who had HBV viral load results available for triage assessment. The median gestational age at the time of HBV testing was 17 weeks.

Sixty $(22.6 \%)$ pregnant women were HBV carriers with viral loads of $\geq 200000 \mathrm{IU} / \mathrm{mL}$; highest level was $688000000 \mathrm{IU} / \mathrm{mL}$. The median age of women with high viral loads was not substantially lower than that of women with low viral loads (33 years vs 35 years; Wilcoxon rank sum test; not significant).

Fifty eight of the 60 patients with high viral loads were scheduled for hepatological review before the expected date of delivery. First hepatological review appointments were scheduled for 55 (91.7\%) women and $44(73.3 \%)$ women at or before 32 and 28 weeks of gestation, respectively. Among the three women who scheduled their first hepatological review appointment after 32 weeks of gestation, two delayed the referral submission and one had attended the antenatal clinic at an advanced stage of gestation (Fig 2).

One patient did not attend a hepatological review appointment before 28 weeks of gestation. The remaining 57 women with high viral loads received antenatal counselling regarding TDF and 56 women agreed to take the drug, thereby constituting an antenatal acceptance rate of $96.6 \%$ (56/58). The acceptance rates of TDF among women with high viral loads are shown in the Table.

Treatment with TDF commenced at a median gestational age of 26 weeks (range, 20-38 weeks). Overall, 44 (78.6\%) women received $300 \mathrm{mg}$ daily TDF at or before 28 weeks of gestation. Among the 12 women who began TDF treatment after 28 weeks of gestation, four had deferred blood tests for assessment of viral load, six had late antenatal clinic appointments, one did not attend the initial appointment at 28 weeks, and one attended the clinic at 33 weeks of gestation. Overall, 52 (92.9\%) women commenced TDF treatment at or before 32 weeks of gestation.

\section{Discussion}

Screening for HBV carrier status is a universal antenatal test in Hong Kong. Women who have positive screening results are counselled regarding the risk of vertical transmission. In 1983, a neonatal HBV vaccination programme was introduced in Hong Kong to cover vaccination for first newborns of carrier mothers. This became universal in November 1988; hepatitis B immunoglobulin and hepatitis B vaccine have since been administered to all babies born to mothers carrying HBV. These measures focus mainly on postnatal neonatal immunoprophylaxis; however, they lack a robust system for actively reducing the antenatal risk of vertical transmission, as well as a referral system that ensures long-term hepatological follow-up for carrier mothers.

The present study demonstrated an effective and acceptable approach involving HBV DNA testing during triage of obstetric patients for prevention of perinatal HBV transmission. Data from the Centre 
of Health Protection have shown that the HBsAg prevalence in pregnant women is decreasing, from $>10 \%$ in the early 1990 s to $5.0 \%$ in $2017 .{ }^{13}$ The HBV carrier rate in the present study (2.9\%) was lower than that previously reported in Hong Kong. Our cohort included women with HBsAg who were tested from May 2017 to December 2019; the low carrier rate in the present study might reflect a continuous reduction in overall $\mathrm{HBsAg}$ prevalence, due to universal neonatal vaccination. ${ }^{14}$ However, more than $70 \%$ of the pregnant women in our cohort did not have HBV viral load testing or regular hepatological surveillance before pregnancy. This is an important public health concern, because HBV carriers with high viral loads are at higher risk of mother-to-child transmission of HBV, as well as development of liver cirrhosis and hepatocellular carcinoma. With proper antenatal education and general awareness, nearly $98 \%$ of the obstetric patients in our population were willing to undergo self-financed HBV DNA testing.

Viral load is a key factor that influences immunoprophylaxis failure ${ }^{4}$; a higher risk of immunoprophylaxis failure has been demonstrated in women with viral loads of $\geq 200000 \mathrm{IU} / \mathrm{mL}$. Positive $\mathrm{HBeAg}$ screening results, maternal age $<35$ years, and body mass index $\leq 21 \mathrm{~kg} / \mathrm{m}^{2}$ have been associated with a higher mean viral load. ${ }^{15}$ Our study showed that $22.6 \%$ of women had viral loads of $\geq 200000 \mathrm{IU} / \mathrm{mL}$, which was comparable to previous findings. Although age was not a statistically significant factor in the present study, a previous study showed that women with high viral loads were younger than women with low viral loads. ${ }^{5}$ The prevention of perinatal transmission is of considerable importance in achieving complete eradication of HBV. Incorporation of HBV DNA testing during pregnancy is a key element that can facilitate identification of at-risk pregnant women who may benefit from antenatal antiviral prophylaxis. Ideally, both liver function test and HBeAg should be assessed in pregnant women to determine their HBV disease status; antiviral treatment may be initiated for maternal indications. Although the presence of HBeAg suggests a high risk of immunoprophylaxis failure, $\mathrm{HBeAg}$ was not routinely assessed during triage in the present cohort because it was not regarded as an indicator of the need for antiviral treatment to prevent vertical transmission. ${ }^{9,16,17}$ Additionally, HBV DNA quantification provides a continuous assessment of risk according to viral load, compared to the dichotomous result of $\mathrm{HBeAg}$ screening. Therefore, HBV DNA level should be used to identify women who should receive antiviral treatment. $^{18}$

Tenofovir disoproxil fumarate is the drug of choice for antenatal prophylaxis because of its potent effect and the possibility of mutants
TABLE. Acceptance of hepatological review and tenofovir disoproxil fumarate treatment among 60 pregnant women with high hepatitis $B$ viral load $(\geq 200000 \mathrm{lU} / \mathrm{mL})^{*}$

\begin{tabular}{|c|c|}
\hline $\begin{array}{l}\text { First hepatological review appointment before expected date of } \\
\text { delivery }\end{array}$ & $58(96.7 \%)$ \\
\hline First antenatal visit at term & $1(1.7 \%)$ \\
\hline Delivery before clinic appointment & $1(1.7 \%)$ \\
\hline $\begin{array}{l}\text { First hepatological review appointment at or before } 32 \text { weeks of } \\
\text { gestation }\end{array}$ & $55(91.7 \%)$ \\
\hline $\begin{array}{l}\text { First hepatological review appointment at or before } 28 \text { weeks of } \\
\text { gestation }\end{array}$ & $44(73.3 \%)$ \\
\hline Antenatal tenofovir disoproxil fumarate treatment & $56(93.3 \%)$ \\
\hline Commenced at or before 28 weeks & $44 / 56(78.6 \%)$ \\
\hline Commenced after 28 weeks & $12 / 56(21.4 \%)$ \\
\hline Commenced after 32 weeks & $4 / 56(7.1 \%)$ \\
\hline No antenatal prophylaxis & $4(6.7 \%)$ \\
\hline Delivery before hepatological review & $2(3.3 \%)$ \\
\hline Refused prophylaxis & $1(1.7 \%)$ \\
\hline Did not attend hepatological review appointment after DNA test & $1(1.7 \%)$ \\
\hline
\end{tabular}

resistant to lamivudine and telbivudine, due to prior treatment with those drugs. ${ }^{11,12,19}$ Breastfeeding is not contra-indicated for women who are taking TDF. A highly promising rate of antenatal acceptance of TDF (96.6\%) was observed among women who had undergone antenatal hepatological review. This indicates the need for surveillance and the usefulness of patient education during the antenatal period.

Although the optimal timing of antiviral treatment remains controversial, randomised controlled trials show that initiation of TDF during the period between 28 and 32 weeks of gestation is effective in reduction of immunoprophylaxis failure. Earlier initiation of antiviral treatment is unnecessary, because the immunoprophylaxis failure rate is not appreciably reduced. Postponement of treatment to a point later than 32 weeks of gestation may result in an insufficient duration of treatment and suboptimal viral load reduction at delivery. ${ }^{10,20}$ Guidelines from the American Association for the Study of Liver Diseases and the Asian Pacific Association for the Study of the Liver recommend initiation of treatment at 28 to 32 weeks of gestation. ${ }^{9,21}$ The present study demonstrated a feasible framework for triage of nearly all pregnant women with high viral loads before their dates of delivery. Nearly $93 \%$ were able to initiate antiviral prophylaxis at or before 32 weeks of gestation; this could only be attained with an appropriate hepatological review appointment during pregnancy. The arrangement could be further improved if women could attend antenatal visits earlier during pregnancy, blood test logistics could be simplified, and resources could be allocated more effectively. 


\section{Conclusion}

To the best of our knowledge, the multidisciplinary efforts of obstetricians and hepatologists have enabled Queen Mary Hospital to become the first public hospital in Hong Kong with enhanced antenatal management for pregnant women carrying hepatitis B. The proportion of women with high viral loads was comparable to the proportions in previous studies. Our results indicated the usefulness of HBV DNA blood tests in pregnant women and high acceptance of antenatal antiviral treatment. Triage according to HBV DNA level allowed early hepatological review and commencement of antiviral medication, thereby reducing the viral load at the time of delivery and minimising the risk of vertical transmission. This service model was adopted as a framework for implementation of a fully funded enhanced antenatal service to prevent mother-to-child transmission of HBV in public maternity units, commencing 1 January 2020.

\section{Author contributions}

Concept or design: PW Hui.

Acquisition of data: C Ng, PW Hui.

Analysis or interpretation of data: $\mathrm{C} \mathrm{Ng}, \mathrm{PW}$ Hui.

Drafting of the manuscript: PW Hui.

Critical revision of the manuscript for important intellectual content: KW Cheung, CL Lai.

All authors had full access to the data, contributed to the study, approved the final version for publication, and take responsibility for its accuracy and integrity.

\section{Conflicts of interest}

All authors have disclosed no conflicts of interest.

\section{Acknowledgement}

The authors thank Mr John Yuen for performing HBV DNA analysis.

\section{Funding/support}

This research received no specific grant from any funding agency in the public, commercial, or not-for-profit sectors.

\section{Ethics approval}

This research was approved by the Institutional Review Board of the University of Hong Kong / Hospital Authority West Cluster (Ref UW 20-092).

\section{References}

1. World Health Organization. Global Health Sector Strategy on viral hepatitis 2016-2021, towards ending viral hepatitis. 2016. Available from: http://apps.who.int/iris/ bitstream/handle/10665/246177/WHO-HIV-2016.06-eng. pdf?sequence=1. Accessed 2 Feb 2020.

2. Edmunds WJ, Medley GF, Nokes DJ, Hall AJ, Whittle HC. The influence of age on the development of the hepatitis $B$ carrier state. Proc Biol Sci 1993;253:197-201.

3. Lee C, Gong Y, Brok J, Boxall EH, Gluud C. Effect of hepatitis $B$ immunisation in newborn infants of mothers positive for hepatitis B surface antigen: systematic review and meta-analysis. BMJ 2006;332:328-36.

4. Cheung KW, Seto MT, Wong SF. Towards complete eradication of hepatitis $\mathrm{B}$ infection from perinatal transmission: review of the mechanisms of in utero infection and the use of antiviral treatment during pregnancy. Eur J Obstet Gynecol Reprod Biol 2013;169:17-23.

5. Cheung KW, Seto MT, Kan AS, et al. Immunoprophylaxis failure of infants born to hepatitis B carrier mothers following routine vaccination. Clin Gastroenterol Hepatol 2018;16:144-5.

6. Wen WH, Chang MH, Zhao LL, et al. Mother-to-infant transmission of hepatitis B virus infection: significance of maternal viral load and strategies for intervention. J Hepatol 2013;59:24-30.

7. Zou H, Chen Y, Duan Z, Zhang H, Pan C. Virologic factors associated with failure to passive-active immunoprophylaxis in infants born to $\mathrm{HBsAg-positive}$ mothers. J Viral Hepat 2012;19:e18-25.

8. European Association for the Study of the Liver. EASL 2017 Clinical Practice Guidelines on the management of hepatitis B virus infection. J Hepatol 2017;67:370-98.

9. Terrault NA, Lok AS, McMahon BJ, et al. Update on prevention, diagnosis, and treatment of chronic hepatitis B: AASLD 2018 hepatitis B guidance. Hepatology 2018;67:1560-99.

10. Pan CQ, Duan Z, Dai E, et al. Tenofovir to prevent hepatitis $\mathrm{B}$ transmission in mothers with high viral load. $\mathrm{N}$ Engl J Med 2016;374:2324-34

11. Hyun MH, Lee YS, Kim JH, et al. Systematic review with meta-analysis: the efficacy and safety of tenofovir to prevent mother-to-child transmission of hepatitis B virus. Aliment Pharmacol Ther 2017;45:1493-505.

12. Hu YH, Liu M, Yi W, Cao YJ, Cai HD. Tenofovir rescue therapy in pregnant females with chronic hepatitis $B$. World J Gastroenterol 2015;21:2504-9.

13. Viral Hepatitis Control Office, Special Preventive Programme, Centre for Health Protection, Department of Health, Hong Kong SAR Government. Surveillance of Viral Hepatitis in Hong Kong-2017 Update Report. Available from: https://www.chp.gov.hk/files/pdf/viral_hepatitis_ report.pdf. Accessed 2 Feb 2020.

14. Lao TT, Sahota DS, Chan PK. Three decades of neonatal vaccination has greatly reduced antenatal prevalence of hepatitis $B$ virus infection among gravidae covered by the program. J Infect 2018;76:543-9.

15. Cheung KW, Seto MTY, So PL, et al. Optimal timing of hepatitis B virus DNA quantification and clinical predictors for higher viral load during pregnancy. Acta Obstet Gynecol Scand 2019;98:1301-6.

16. $\mathrm{Hu}$ Y, Xu C, Xu B, et al. Safety and efficacy of telbivudine in late pregnancy to prevent mother-to-child transmission of hepatitis B virus: a multicenter prospective cohort study. J Viral Hepat 2018;25:429-37.

17. Jourdain G, Ngo-Giang-Huong N, Harrison L, et al. Tenofovir versus placebo to prevent perinatal transmission of hepatitis B. N Engl J Med 2018;378:911-23.

18. Cheung KW, Lao TT. Hepatitis B-Vertical transmission and the prevention of mother-to-child transmission [in press]. Best Pract Res Clin Obstet Gynaecol. In press.

19. Cheung KW, Seto MT, Lao TT. Prevention of perinatal hepatitis B virus transmission. Arch Gynecol Obstet 2019;300:251-9.

20. Yang X, Zhong X, Liao H, Lai Y. Efficacy of antiviral therapy during the second or the third trimester for preventing mother-to-child hepatitis B virus transmission: a systematic review and meta-analysis. Rev Inst Med Trop Sao Paulo 2020;62:e13.

21. Sarin SK, Kumar M, Lau GK, et al. Asian-Pacific clinical practice guidelines on the management of hepatitis $B$ : a 2015 update. Hepatol Int 2016;10:1-98. 